\title{
Coincidental Lung Mass Diagnosis in COVID-19 Infected Patient: A Case Report
}

\author{
Korona Virus Enfekte Olguda Rastlantısal Akciğer Kitle Tanısı: Bir Olgu Sunumu
}

\section{Turkan Ikizceli ${ }^{1}$, Serhat Aras ${ }^{2}$, (D) Rustu Turkay ${ }^{1}$, iD Nurdan Gocgun ${ }^{1}$, (D) Bahar Atasoy Badur ${ }^{1}$, Sevim Ozdemir ${ }^{1}$ \\ 1-Sağlık Bilimleri Üniversitesi, Haseki Sağlık Uygulama ve Araștırma Merkezi, Radyoloji Anabilim Dalı, İstanbul. 2-Sağlık} Bilimleri Üniversitesi, Meslek Yüksek Okulu, Görüntüleme Teknikleri, İstanbul

\section{ABSTRACT}

Introduction: COVID-19 (Corona Virus Disease-19) is a newly discovered virus that caused pandemic infection worldwide. The imaging methods are crucial for diagnosis and follow-up in this infectious period. In this article, a case with coronavirus, which was diagnosed as lung cancer incidentally, is presented. Case report: A 41-year-old man presented to the emergency room with cough, fever, and shortness of breath. On examination, breathing sounds changed by listening in the lung. Lung computerized tomography was performed due to shortness of breath while waiting for the PCR test. In addition to the findings of atypical viral pneumonia compatible with coronavirus infection in the tomography, there was a 44x64mm mass in the right lung middle lobe. Coronavirus treatment was initiated in the patient, whose PCR test was positive. The patient who responded to the treatment after one week was diagnosed as lung cancer as a result of the biopsy.

Conclusion: In the diagnosis of COVID-19, imaging has a crucial role. Incidental findings are commonly detected by computed tomography.

ÖZET

Giriş: Korona virus tüm dünyada pandemiye neden olan yeni keşfedilmiş bir virustur. Görüntüleme yönteminin tanı ve takite oldukça önemli olduğu görülmüş̧ür. Bu yazıda 41 yaşında korona enfeksiyonu esnasında çekilen bilgisayarlı toraks tomografisi ile insidental olarak akciğer kanseri tanısı alan bir olgu sunulmuștur.

Olgu Sunumu: 41 yaşında erkek hasta öksürük, ateş ve nefes darlı̆̆ ile acil servise başvurdu. Muayenesinde akciğerde dinlemekle solunum sesleri değişmişti. PCR testi yapılan olguda nefes darllğl olması nedeniyle Akciğer bilgisayarlı tomografi çekildi. Tomografide korona virus enfeksiyonu ile uyumlu atipik viral pneumoni bulgularının yanında săg akciğer orta lobda $44 x 64 \mathrm{~mm}$ kitle mevcuttu. PCR testi pozitif gelen olgunun korona virus tedavisi başland. 1 hafta sonra tedaviye cevap veren olguda biyopsi sonucu akciğer kanseri tanısı konuldu.

Sonuç: Korona virus enfeksiyon tanisında görüntüleme oldukça önem arzetmektedir. İnsidental bulgular sıklıkla Bilgisayarlı Tomografi tarafindan tespit edilmiştir.
\end{abstract}

\section{INTRODUCTION}

COVID-19 (Corona Virus Disease-19) is a newly discovered virus that caused pandemic infection worldwide. COVID-19 virus is a contagious infection that causes mild to moderate respiratory disease and recover without special treatment. Older people and those with underlying medical problems such as cardiovascular disease, diabetes, chronic respiratory disease, and cancer are more likely to develop serious illnesses (1). Imaging is very crucial to diagnose and follow-up. However, computed tomography (CT) is not recommended for COVID-19 screening and diagnosis. Meanwhile, it plays an essential role in treating patients with new diseases and ruling out alternative diagnoses or co-existing disorders (2).

We present a case of COVID-19 infected patient that incidentally diagnosed lung cancer detected by CT scan.

\section{CASE}

A 41-year-old man presented to the emergency room with cough, fever, and shortness of breath. The patient had a family history of patient contact with corona. On examination, breathing sounds changed by listening in the lung. His vital signs were: blood pressure 120/70 mm $\mathrm{Hg}$, heart rate 92 beats per minute, respiratory rate 18 breaths per minute, and temperature $38.1^{\circ} \mathrm{C}$. Laboratory findings; $\mathrm{WBC}=14.3210^{3} / \mathrm{mm}^{3}, \mathrm{HGB}=13.4 \mathrm{~g} / \mathrm{dL}$, $\mathrm{NEU}=11.2 \mathrm{uL}, \mathrm{NEU} \%=78.2, \mathrm{CRP}=236.6 \mathrm{mg} / \mathrm{L}$. First of all, the RT-PCR test performed, but he had a symptom of dyspnea. We decided to perform a non-contrast thorax CT scan due to shortness of breath while waiting for the PCR test. CT findings showed that bilateral peripheric ground-glass opacities and subsegmental consolidation. Also, the results of atypical viral pneumonia compatible with coronavirus infection (figure 1a, b); there was a 44x64 mm mass in the right lung middle lobe (figure 2a, b). The mass was up to the heart's right atrium and adjacent to the vascular 


\section{Ikizceli et al.}

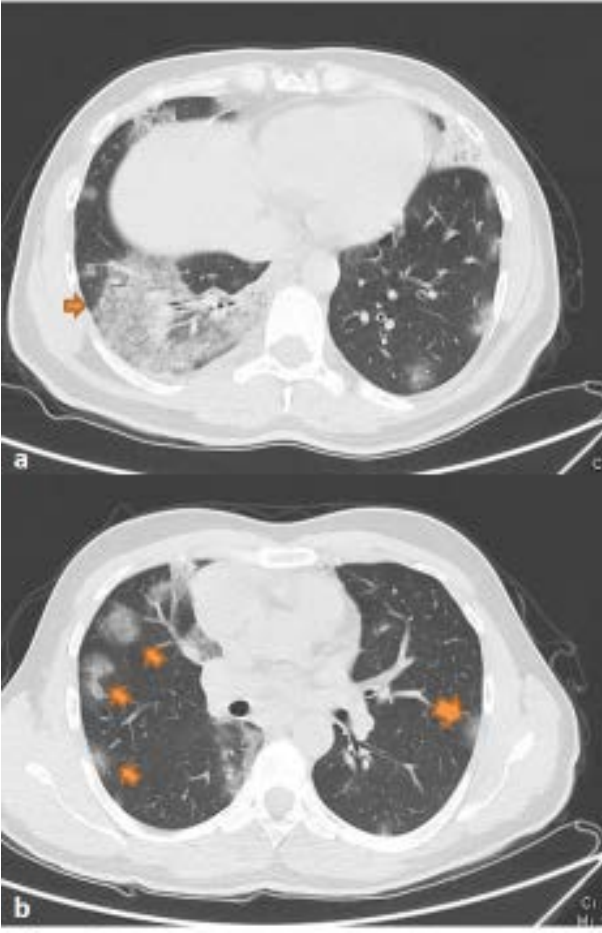

Figure 1: a) Axial CT scan shows that subsegmental consolidation (arrow)

b) bilateral, multiple, rounded

ground-glass opacities (arrows)

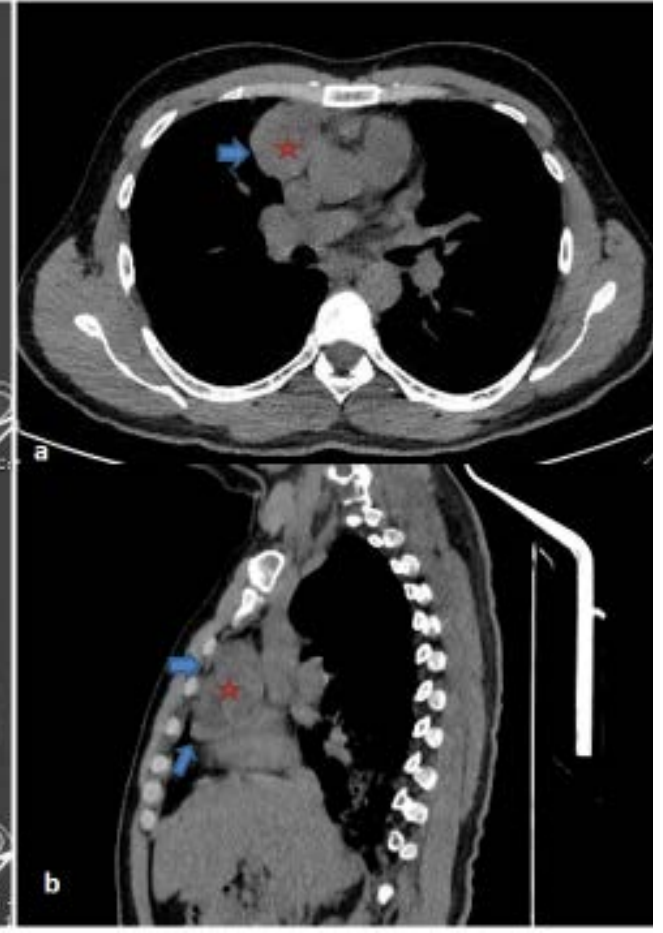

Figure 2: a) Axial ve b) sagittal CT images of the patient. The mass (star) adjacent to the vascular area. structures in the mediastinal structures. Coronavirus treatment was initiated in the patient, whose PCR test was positive. The patient who responded to the treatment after one week was diagnosed as lung cancer as a result of the biopsy. Informed consent was obtained from the patient for the publication of this manuscript.

\section{DISCUSSION}

COVID-19 (Corona Virus Disease-19) is a zoonotic illness first reported in the city of Wuhan, China, in December 2019, and is now officially a global pandemic as declared by the World Health Organization. The infection is caused by severe acute respiratory syndrome coronavirus 2 (SARS-CoV-2). COVID-19 infected patients can be asymptomatic carriers or present with mild-to-severe respiratory symptoms (3). The most common symptoms are fever, cough, and tiredness. Less common symptoms; sore throat, muscle pain, diarrhea, conjunctivitis, headache, the new loss of taste or sense of smell, rash on the skin. Serious symptoms: trouble breathing or shortness of breath, chest pain, or pressure in the chest, loss of speech, new confusion, or inability to stay awake. The presence of one of these is a sign that emergency medical care is needed (4). Older adults and people who have severe underlying medical conditions like heart or lung disease or diabetes seem to be at higher risk for developing more serious complications from COVID-19 illness $(3,4)$.

Two kinds of tests are available for COVID-19 to diagnose: viral tests (RT-PCR) and antibody tests (IgM and IgG). SARS-CoV-2 RNA is identified by RT-PCR (5). No matter the type of test, if anyone has a positive test, you should take preventive measures to protect yourself and others. Most people get a mild illness and can recover without medical care at home and need not be tested (5). Additional laboratory tests, including $\mathrm{CBC}$, are generally nonspecific. The leukocyte count is frequently normal or low, might be lymphopenia; a lymphocyte count $<1.000$ has been related to severe disease. The thrombocyte count is generally normal or slightly depressed. The ALT/AST, prothrombin time, creatinine, D-dimer, CPK, LDH, myohemoglobin, and ferritin levels might be increased, and elevated levels might be related to severe disease (6). High D-dimer levels and more severe lymphopenia have been shown to be linked with fatality (7). In our case, laboratory findings were similar.

Imaging in COVID-19 The lung X-ray (CXR) generally shows bilateral infiltrations but may be normal in the early phase of the disease. The chest CT is more sensitive and specific. CT findings of COVID-19 have been widely reported. Lung CT scans generally demonstrate infiltrates, ground-glass opacities, and subsegmental consolidation. Less common abnormalities contain pleural effusion/thickening, and lymphadenopathy. During the early phase of COVID-19 disease, thorax CT shows multiple small plaques and interstitial alterations, evident in the lung periphery, further worsens to bilateral multiple ground-glass 
opacity and/or infiltrating shadows. Pulmonary consolidation may happen in severe cases. Pleural effusion is infrequently observed $(1,8)$. In our case, there were a large number of peripheral rounded multiple ground ground-glass densities on CT. A younger patient, such as a 41-year-old for lung cancer, had a biopsy-verified lung mass in the middle lobe of the right lung. Pathologic lung CT imaging has also been utilized to identify COVID-19 is suspected and/or asymptomatic cases with negative RT-PCR; many of them become to have positive PCR when they are repeated (9-11).

\section{CONCLUSION}

CT gives essential information during the COVID-19 pandemic, primarily to diagnose some patients with underlying disease. A negative RT-PCR test does not exclude the diagnosis, and an unenhanced CT should be performed. Incidental findings are commonly detected by computed tomography.

Conflicts of Interest

All other co-authors have no conflicts of interest.

\section{REFERENCES}

1. Das KM, Lee EY, Al Jawder SE, Enani MA, Singh R, Skakni L, et al. Acute Middle East Respiratory Syndrome Coronavirus: Temporal Lung Changes Observed on the Chest Radiographs of 55 Patients. AJR Am J Roentgenol. 2015 Sep;205(3): W267-74.

2. Zhong Z, Hu Y, Yu Q, Li Y, Li P, Huang W, et al. Multistage CT features of coronavirus disease 2019. Zhong Nan Da Xue Xue Bao Yi Xue Ban. 2020 Mar 28;45(3):250-256.

3. Bhat R, Hamid A, Kunin JR, Saboo SS, Batra K, Baruah D et al. Chest Imaging in Patients Hospitalized With COVID-19 Infection - A Case Series. Curr Probl Diagn Radiol. 2020 Apr 11. pii: S0363-0188(20)30055-4.

4. Grasselli G, Pesenti A, Cecconi M. Critical Care Utilization for the COVID-19 Outbreak in Lombardy, Italy: Early Experience and Forecast During an Emergency Response. JAMA. 2020 Mar 13. doi:10.1001/jama.2020.4031.

5. Ozdemir O. Coronavirus Disease 2019 (COVID-19): Diagnosis and Management (Narrative Review). Erciyes Med J 2020; 42(3): 00-00 DOI: 10.14744/etd.2020.99836.

6. Huang C, Wang Y, Li X, Ren L, Zhao J, Hu Y, et al. Clinical features of patients infected with 2019 novel coronavirus in Wuhan, China. Lancet 2020; 395(10223): 497-506.

7. Chen N, Zhou M, Dong X, Qu J, Gong F, Han Y, et al. Epidemiological and clinical characteristics of 99 cases of 2019 novel coronavirus pneumonia in Wuhan, China: a descriptive study. Lancet 2020; 395(10223): 507-13.

8. Bai HX, Hsieh B, Xiong Z, Halsey K, Choi JW, Tran TML, et al. Performance of radiologists in differentiating COVID-19 from viral pneumonia on chest CT. Radiology. 2020 Mar 10:200823. doi: 10.1148/radiol.2020200823.

9. Huang P, Liu T, Huang L, Liu H, Lei M, Xu W, et al. Use of chest CT in combination with negative RT-PCR assay for the 2019 novel coronavirus but high clinical suspicion. Radiology 2020; 295(1): 22-3.

10. Albano D, Bertagna F, Bertoli M, Bosio G, Lucchini S, Motta F, et al. Incidental Findings Suggestive of COVID-19 in Asymptomatic Patients Undergoing Nuclear Medicine Procedures in a High-Prevalence Region. J Nucl Med. 2020 May;61(5):632-636.

11. Karcıoğlu Ö. What is Coronaviruses, and how can we protect ourselves? Phnx Med J. 2020; March, 2 (1): 66-71. 